\title{
QUALITY ANALYSIS OF DRINKING WATER IN BHOPAL CITY
}

\author{
Aman Gaur ${ }^{1}$, Shashank Chourey ${ }^{2}$, Deepa Madathil ${ }^{3}$, A. N. Brijesh Nair \\ ${ }^{1}$ Undergraduate Student, School of Mechanical \& Building Sciences, VIT University, Vellore, India \\ ${ }^{2}$ Undergraduate Student, School of Mechanical \& Building Sciences, VIT University, Vellore, India \\ ${ }^{3}$ Assistant Professor, School of Bio Sciences and Technology, VIT University, Vellore, India \\ ${ }^{4}$ Professor, School of Mechanical \& Building Sciences, VIT University, Vellore, India
}

\begin{abstract}
Safe-Water crisis is one of the major crises that the world is facing today. It's not about responsibility, it's our duty to plan for water management and look for sources that can provide us clean and clear water. In a city where the population is increasing with respect to sources available, efficient use of water resource becomes much more important. Kolar Water Treatment Plant located in Bhopal, capital city of Madhya Pradesh is the biggest source of drinking water to a population of around 1.8 millions. This study was carried out for quality assessment of Kolar Water treatment plant.Complete data was collected and tabulated for a period of 6 months, and the performance of the plant was evaluated on the basis of the variation observed in parameters such as turbidity, alum dosage, $\mathrm{pH}$, lime content. Climatic variation of the city also had a major impact on the performance of the plant .Results were compared to the existing BIS ( Bureau of Indian Standards) and it was concluded that almost all parameters were well within the permissible range
\end{abstract}

Keywords: Water Treatment, Bhopal, Water Quality Parameters, Drinking water

\section{INTRODUCTION}

Bhopal is a city of modern era, developing and balancing its history, scenic beauty, greenery and new infrastructure. Also, it is the capital of the state Madhya Pradesh and is known as "The City of Lakes". It is located in the central part of India [1]. It is over $285 \mathrm{~km}^{2}$ in area and comes under Bhopal Municipal Corporation (BMC) [2]. It has a population of 1,795,648 according to the 2011 Census. It has the coordinates as $23.2500^{\circ} \mathrm{N}$ latitude and $77.4200^{\circ} \mathrm{E}$ longitude [1].

The city has 'humid tropical season' having hot summers and cool winters. It receives moderate pouring of rain within the monsoon season (July - September), which varies yearly. The average temperature range of the city is $25^{\circ} \mathrm{C}$ $30^{\circ} \mathrm{C}$ and humidity is quite high [1]. It incorporates many geological features as mountains, plateaus, and small hills within its boundaries. It lies in the Malwa plateau. It has uneven elevations and has an average elevation of 500 metres $(1401 \mathrm{ft})$ above the mean sea level (MSL). The major source of drinking water comes from the lakes and dams for the residents [4]. It has two lakes locally known as 'the Upper Lake' and 'the Lower Lake'. The catchment area of the Upper and the Lower Lakes are $360 \mathrm{~km}^{2}$ and $9.6 \mathrm{~km}^{2}$ respectively [1].

The BMC officials projected that the projected population of Bhopal in the year 2022 will be 2.75 millions and will require 458 millions litres per day (MLD) of water supply at a rate of 150 litres of water per head. The estimated population in the year 2015 will be 21 lakhs for which 362 MLD of water supply is required. At present, they take 95 MLD of water from the Upper Lake and 155 MLD from the Kolar Dam. The remaining 112 MLD of water will be supplied from the Narmada Project which has a capacity of 185 MLD. If intake of 70 MLD water from the Upper Lake is stopped, it will increase the water level of the Upper Lake [5].

As the city is developing rapidly, there is a huge increase in the migration of people from nearby villages and town. The basic three needs of a person are food, water and shelter. The municipal corporation of Bhopal is able to satisfy the public with two of the needs (food and shelter) but has a tough time in making the water available to them. As stated earlier, the source of water for the public is with the help of two lakes and dams but the refilling depends upon the monsoon. In the years when the monsoon is not good, there is a high crisis of water in the summers and winters.

To satisfy the need for water, the corporation has established a $70 \mathrm{~km}$ pipeline from the river Narmada into the state capital carrying 185 MLD of water every day. But, the distribution network is under progress and has to be made ready before circulating it to every house.

Bhopal Municipal Corporation has to supply domestic water to a large mass of public. As the population is rising and meeting the demands is a big opportunity for them, they have already established a Kolar Water Treatment Plant which is $32 \mathrm{Km}$ away from the city [4]. It circulates the domestic water to a current population of 1.8 millions [3].

\section{MATERIALS AND METHODS}

The objective of this study is to find out, if the Bhopal Kolar water treatment plant (WTP) meets the required standards set by the Bureau of Indian Standards. The data was collected for a period of six months from $1^{\text {st }}$ May 2012 to 
$31^{\text {st }}$ October 2012 on the physical and chemical characteristics which define the quality of the raw water and filtered water of the Kolar Water Treatment Plant. In addition to that, the data was also collected on the physical and chemical characteristics which define the quality of treated water of the plant after the end of each unit process for nineteen days from $12^{\text {th }}$ December 2012 to $31^{\text {st }}$ December 2012.

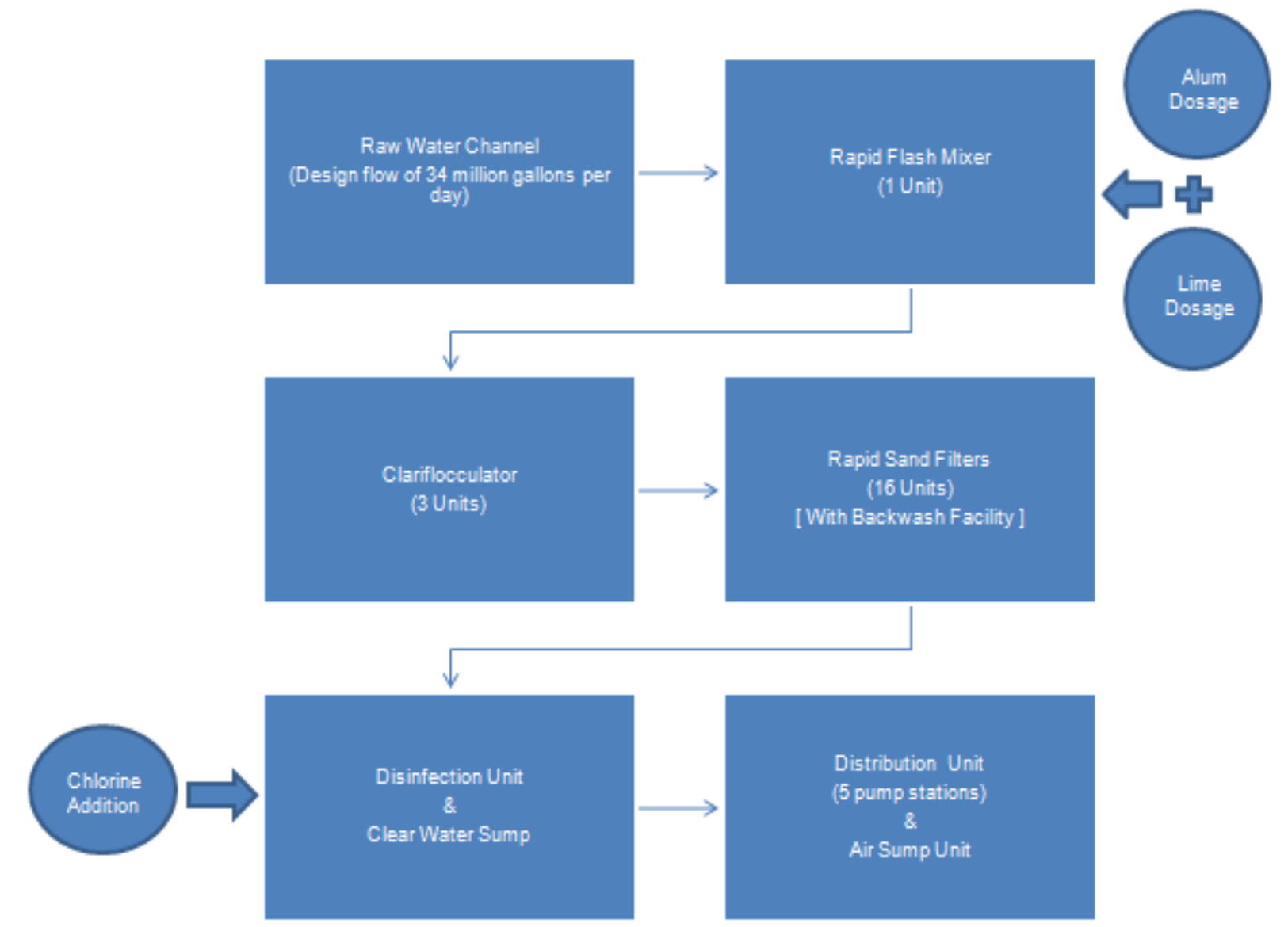

Fig 1 Flow diagram of the Kolr water treatment plant, Bhopal

\section{RESULTS AND DISCUSSIONS}

Table 1 Comparison of the observed average values and peak values of filtered water for six months data of the Bhopal Kolar Water Treatment Plant with Indian drinking water standards (IS: 10500 - 1991)

\begin{tabular}{|c|c|c|c|c|c|}
\hline \multirow[b]{2}{*}{ Parameters } & \multicolumn{2}{|c|}{$\begin{array}{l}\text { Bureau of Indian Standards for } \\
\text { Drinking Water } \\
\text { (IS : 10500-1991) }\end{array}$} & \multicolumn{2}{|c|}{ Observations } & \multirow[b]{2}{*}{ Remarks } \\
\hline & $\begin{array}{l}\text { Desirable } \\
\text { Limit }\end{array}$ & $\begin{array}{l}\text { Permissible } \\
\text { Limit }\end{array}$ & $\begin{array}{l}\text { Observed } \\
\text { Average } \\
\text { Values }\end{array}$ & $\begin{array}{l}\text { Observed } \\
\text { Peak } \\
\text { Values } \\
\end{array}$ & \\
\hline Turbidity (NTU) & 5 & 10 & 1.05 & 2.50 & Within the limit \\
\hline $\begin{array}{l}\mathrm{pH} \\
\text { Value }\end{array}$ & $6.5-8.5$ & No relaxation & 7.49 & 8.90 & Within the limit \\
\hline $\begin{array}{ll}\text { Total Hardness (as } \\
\left.\mathrm{CaCO}_{3}\right)\end{array}$ & 300 & 600 & 107.33 & 128.0 & Moderate \\
\hline Chloride $(\mathrm{mg} / \mathrm{l})$ & 250 & 1000 & 11.11 & 14.0 & Within the limit \\
\hline Sulphate (mg/l) & 200 & 400 & 17.90 & 47.5 & Within the limit \\
\hline Alkalinity (mg/l) & 200 & 600 & 108.08 & 130.0 & Moderate \\
\hline $\begin{array}{ll}\begin{array}{l}\text { Dissolved } \\
(\mathrm{mg} / \mathrm{l})\end{array} & \text { Oxygen } \\
\end{array}$ & 9.20 & 5.0 & 4.64 & 5.2 & Moderate \\
\hline
\end{tabular}


According to the Table 1, all the governing parameters for the quality of drinking water treated by Bhopal Kolar water treatment plant is within the desirable limit of Bureau of Indian Standards except the dissolved oxygen parameter which is little above the permissible limit [6]. The observed average values for six months data is well within the limit. The observed peak value of $\mathrm{pH}$ is above the desirable limit which is noticed mostly during the rainy season during the months of July to September.

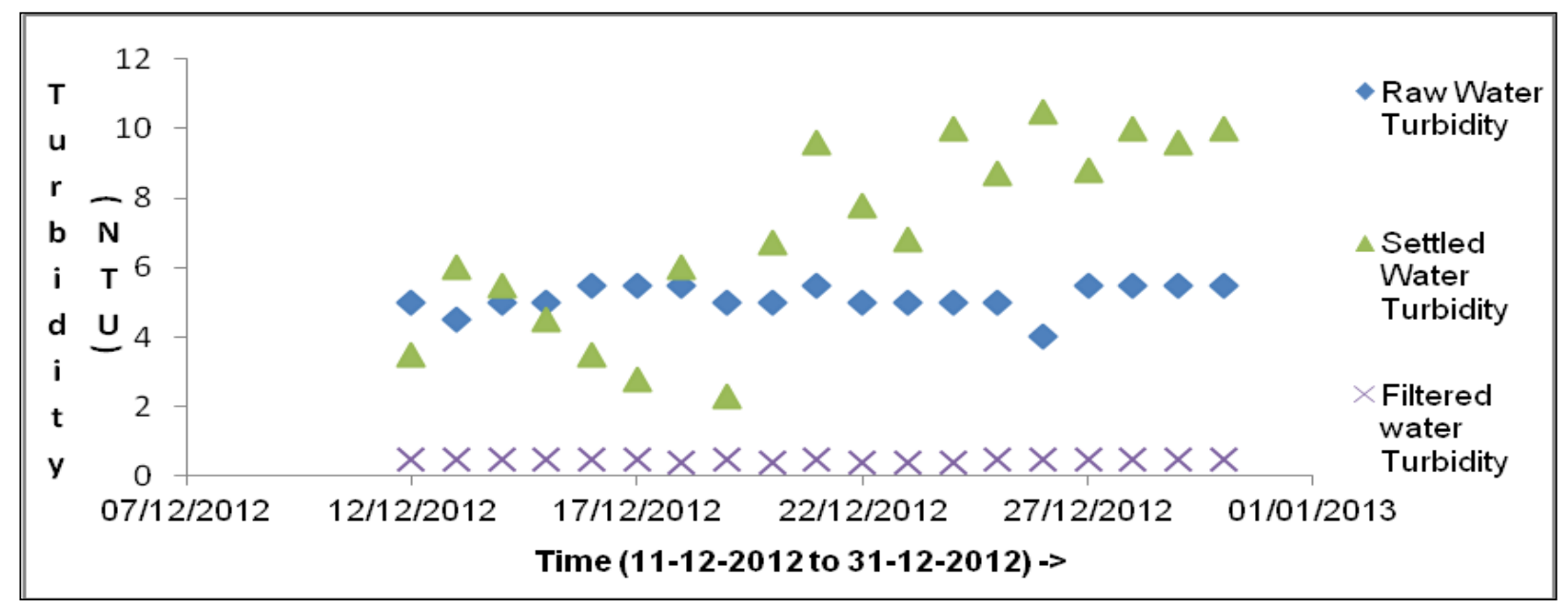

Fig 2 Relation of the turbidity in raw, settled and filtered water of the Bhopal WTP for nineteen days data collected from $12^{\text {th }}$ December 2012 to $31^{\text {st }}$ December 2012.

The above Figure 2 shows that the turbidity of the settled water is above the raw water turbidity for almost $50 \%$ of the nineteen days of testing. It can be related to the over dosage of alum which increases the turbidity in the water. The detention period of clariflocculator should be increased for better settling of the suspended particles during rainy season. It can be also related with the improper coagulation and flocculation mixes. In order to have efficient functioning of the clariflocculator, changes are necessary to be performed as the settled water turbidity should always be lower than the raw water turbidity.

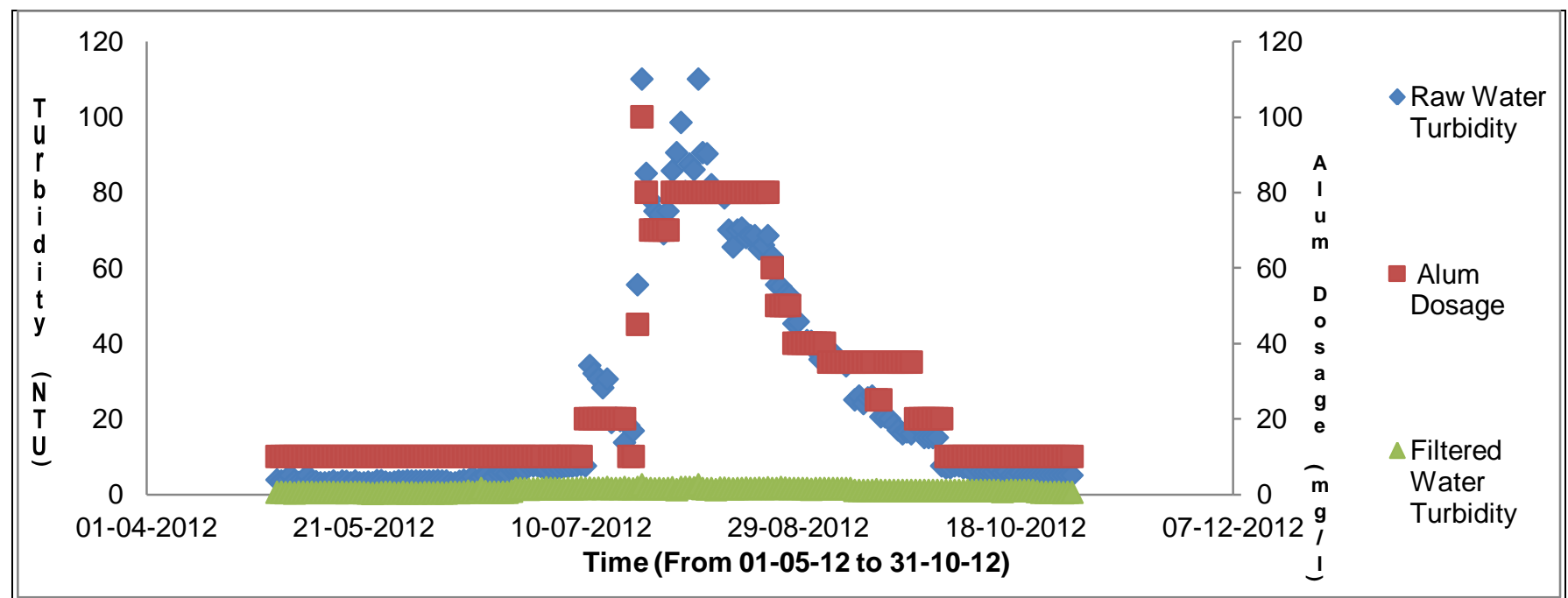

Fig 3 Relation between alum dosage, raw water turbidity \& filtered water turbidity for six months data collected from $1^{\text {st }}$ May 2012 to $31^{\text {st }}$ October 2012.

The percentage turbidity removal efficiency ((raw water turbidity - filtered water turbidity)/ raw water turbidity *100) of the Bhopal Kolar water treatment plant for six months ( $1^{\text {st }}$ May 2012 to $31^{\text {st }}$ October 2012) is on an average of $90.07 \%$. The curve of the graph shows the increase in raw water turbidity from the desirable limit ( $5 \mathrm{NTU}$ ) to an extreme limit of 110 NTU $(\max )$ during the period of the rainy season. Due to high raw water turbidity, the coagulant (alum) dosage also increases from a minimum of $10 \mathrm{mg} / \mathrm{L}$ to a maximum of $80 \mathrm{mg} / \mathrm{L}$ in order to get the desired filtered water turbidity within the desirable limit of the Indian Standards. 


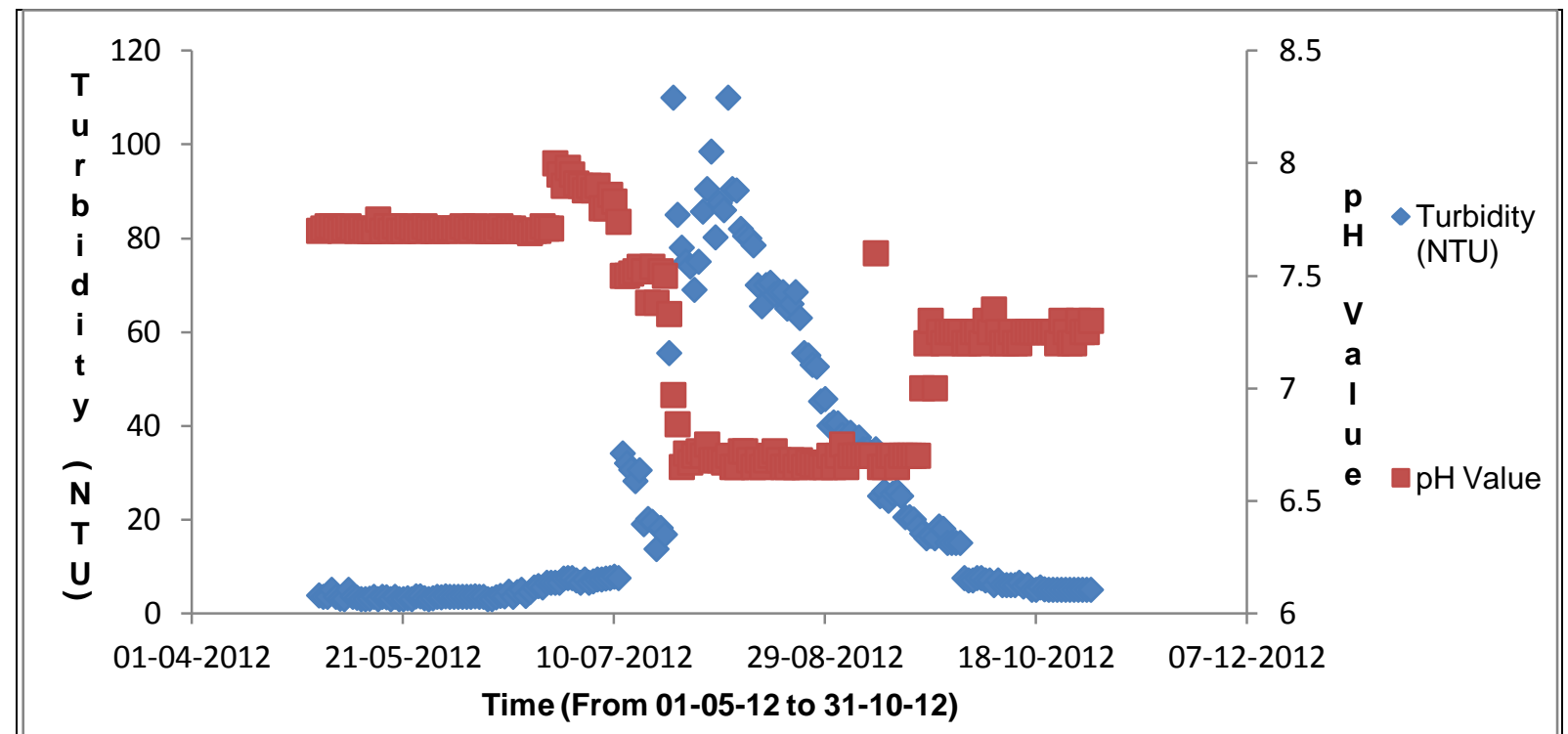

Fig 4 Relation between turbidity and $\mathrm{pH}$ value of raw water for six months data collected from $1^{\text {st }}$ May 2012 to $31^{\text {st }}$ October 2012 .

It can be noticed from the Figure 4 that the $\mathrm{pH}$ value of the raw water is acidic in nature during the rainy season (July September). It can be said that the turbidity and $\mathrm{pH}$ value of raw water are inversely proportional to each other (as rise of turbidity leads to fall of $\mathrm{pH}$ value). A pre-sedimentation tank should be installed which can reduce the turbidity level of the raw water especially during the rainy season. It can also add on to the life of the treatment plant with better functioning and providing better desired results of the filtered water.

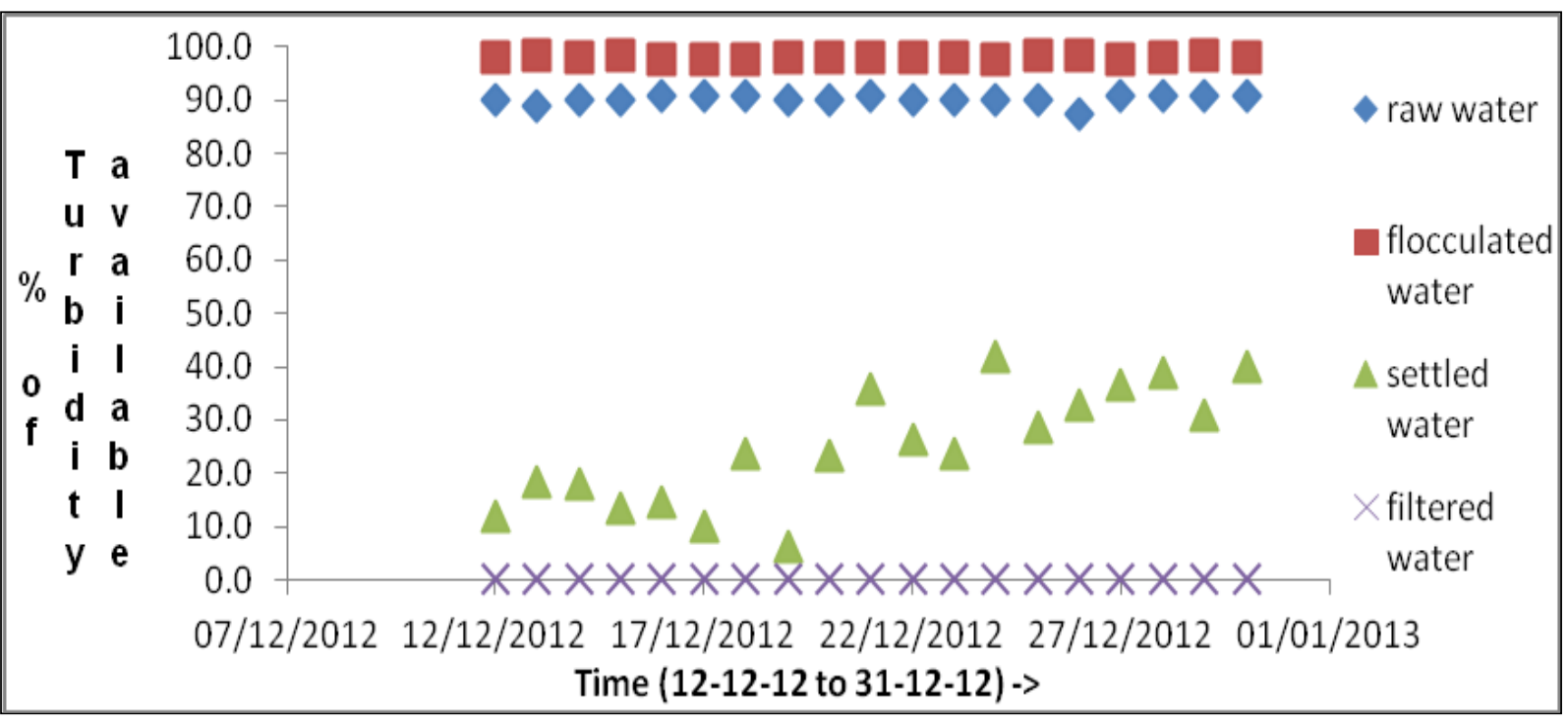

Fig 5 Relation between percentages of turbidity available after each unit process of the Kolar water treatment plant for collected data of nineteen days (from $12^{\text {th }}$ December 2012 to $31^{\text {st }}$ December 2012).

Figure 5 describes the percentage of turbidity available for each unit process ((initial turbidity - final turbidity) / initial turbidity $* 100)$ for nineteen days which shows the amount of the suspended particles being present in water during the treatment process. It can be determined that the major removal of turbidity can be seen after flocculation process in the sedimentation tank.

It can be seen from the figure that the availability of turbidity settled water has as an increasing curve which indicates that the unit did not performed better during the study period. During the initial stage of the study, the operations were performed carefully while adding coagulants or in maintaining the rotational speed of the clariflocculator which did bring out the desired results. The turbidity of the water in the clariflocculator should be lowered as it will improve the efficiency of the plant. 


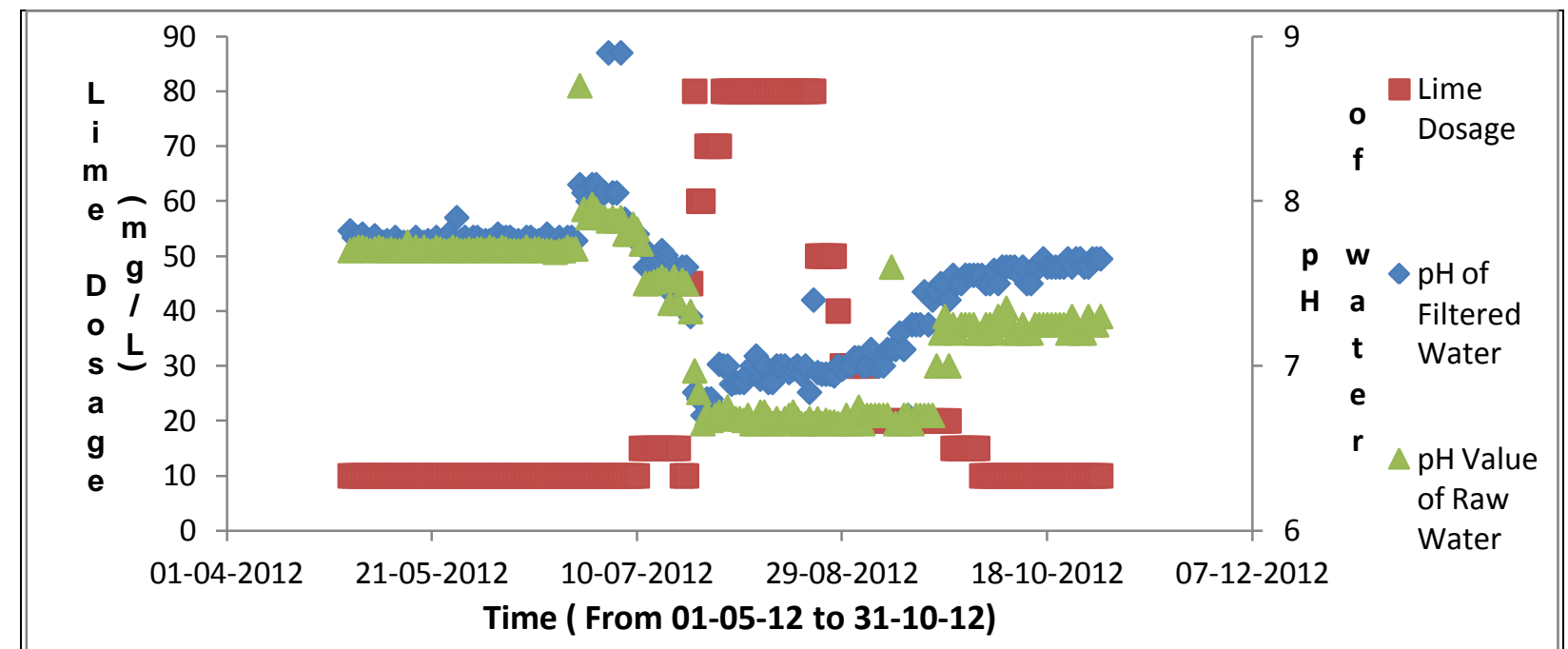

Fig 6 Relation between lime dosage and pH of raw and filtered water from $1^{\text {st }}$ May 2012 to $31^{\text {st }}$ October 2012

Figure 6 describes the effect of lime dosage on the $\mathrm{pH}$ of both the raw water and treated water. Lime is added to control the $\mathrm{pH}$ of the water. During the rainy season i.e. from July to September, it can be seen from the graph that the $\mathrm{pH}$ of raw water has gone below neutral point (7.0) making it more acidic in nature. Hence, the lime content has been increased from a normal dosage of $10 \mathrm{mg} / \mathrm{L}$ to $60 \mathrm{mg} / \mathrm{L}$ during rainy season. It brought the $\mathrm{pH}$ of the filtered water within the desired limit. Since the raw water intake is from the Kolar Dam which is solely dependent upon the rains, the $\mathrm{pH}$ of the water decreases and becomes acidic when the rain water comes in contact with the Kolar dam water. Hence the lime content in water is increased to bring the $\mathrm{pH}$ of the filtered water within the desirable limit of $(6.5-8.5)$.

No tests were performed on man-made chemicals and pharmaceuticals. The fecal coliform was below the detection limit.

\section{CONCLUSION}

It can be concluded that the performance of the city water treatment plant is satisfactory. The treated and distributed drinking water turbidity is within the desirable limit according to Indian Standards (IS 10500-1991). It can also be noted that the critical time of the treatment plant is found out to be during the rainy season. It has noted that $\mathrm{pH}$ and turbidity of the raw water increases beyond the desirable limit during rainy season which affects the efficiency of the treatment plant.

It has been found out that on an average the sedimentation tank removes $24.96 \%$ of turbidity for a period of nineteen days having a detention time of one hour and a half hour. The results are true to their nature. The percentage of removal efficiency of turbidity of the water in the filtration unit is almost $100 \%$ during the study period which makes the treated water drinkable for the people due to efficient handling of equipments and careful addition of chemical dosage in the water.
It can be said that more care to be taken during the rainy season with improved accuracy of measurements and efficient handling of the equipments to obtain better performance of the plant. It can be recommended that unlike currently, the adding of chemicals in the system is being performed manually by the operators, the latest automated equipments should be installed which could enhance the efficiency of the treatment plant. Finally, there should be a better work plan for the Kolar water treatment plant to improve the efficiency and quality of the drinking water by providing them with alternatives for alum, setting the proper detention time of the clariflocculator and introducing various solutions to the existing problems.

\section{ACKNOWLEDGEMENTS}

A sincere acknowledge to the Government of Madhya Pradesh, India for giving the permission to visit the Kolar water treatment plant in Bhopal. A sincere acknowledge also to the Chief Minister and the Mayor of the city Bhopal for promoting to do a detailed research for six month to improve the efficiency of the plant by developing various alternatives and solutions to the existing problems.

\section{REFERENCES}

[1] http://en.wikipedia.org/wiki/Bhopal, Information on Bhopal, capital of Madhya Pradesh state, India. It was last accessed on $18^{\text {th }}$ February 2013.

[2] http://cseindia.org/userfiles/portrait.pdf, The water waste portrait. It was last accessed on $19^{\text {th }}$ February 2013.

[3] http://mckolar.com/sewerage.htm, Municipal Council Kolar, Madhya Pradesh, Government of Madhya Pradesh. It was last accessed on $20^{\text {th }}$ of February 2013.

[4] http://www.bmconline.gov.in/irj/portal/anonymous? guest_user=anonym_en, Bhopal Municipal Corporation, Bhopal, Madhya Pradesh, India. It was last accessed on $18^{\text {th }}$ February 2013. 
[5] http://www.indiawaterportal.org/taxonomy/9/Bureau -of-Indian-Standards-(BIS), Indian Water Portal provides Drinking Water Standards (BIS 10500) of1991 and 2004. It was last accessed on $15^{\text {th }}$ February 2013.

[6] http://www.mpinfo.org/mpinfonew/newsdetails.aspx ?newsid=110217N18\&flag1=1, department of public relations, Madhya Pradesh, Narmada water to reach in April. It was last accessed on $20^{\text {th }}$ February 2013. 